\title{
Intermittent existence of a southern Californian upwelling cell during submillennial climate change of the last $60 \mathrm{kyr}$
}

\author{
I. L. Hendy, ${ }^{1}$ T. F. Pedersen, ${ }^{2}$ J. P. Kennett, ${ }^{3}$ and R. Tada ${ }^{4}$ \\ Received 16 September 2003; revised 24 May 2004; accepted 25 June 2004; published 7 August 2004.
}

[1] Application of a high-resolution multiproxy approach to a sedimentary section drilled at Ocean Drilling Program Site 1017, located under a highly active upwelling cell off Point Conception, California, provides clear evidence for surface ocean productivity shifts on submillennial timescales during the last $60 \mathrm{kyr}$. The proxies include bulk-sediment major and minor elements, organic carbon and carbonate concentrations, $\delta^{15} \mathrm{~N}$, and planktonic foraminiferal species assemblage and carbon isotope determinations. The collective results demonstrate that marine productivity in this area was not simply linearly related to cold and warm cycles except during the millennial-scale climate oscillations of marine isotope stage (MIS) 3. During that interval, the upwelling cell and resulting high productivity were active during warm interstadial events and were largely inactive during cool stadial events. However, the Last Glacial Maximum was also relatively productive. Productivity increased dramatically during the Bølling warm interval, while the Allerød and Younger Dryas were much less productive. High coccolithophorid abundance commenced during the earliest Holocene after $10 \mathrm{ka}$. The complexity of the productivity response was probably related to interplay between local winds, as well as California Undercurrent strength. INDEX TERMS: 4279 Oceanography: General: Upwelling and convergences; 4267 Oceanography: General: Paleoceanography; 4845 Oceanography: Biological and Chemical: Nutrients and nutrient cycling; 4855 Oceanography: Biological and Chemical: Plankton; 4870 Oceanography: Biological and Chemical: Stable isotopes; KEYWORDS: upwelling, productivity, paleoclimate

Citation: Hendy, I. L., T. F. Pedersen, J. P. Kennett, and R. Tada (2004), Intermittent existence of a southern Californian upwelling cell during submillennial climate change of the last $60 \mathrm{kyr}$, Paleoceanography, 19, PA3007, doi:10.1029/2003PA000965.

\section{Introduction}

[2] Strong coastal upwelling along the California Margin has a major influence on local surface water characteristics by depressing sea surface temperatures (SSTs), enriching nutrient concentrations, enhancing biological productivity, and causing local sea level anomalies. Upwelling in this region today is driven by seasonal northerly longshore winds and associated Ekman transport offshore [Lynn and Simpson, 1987], but growing evidence suggests that this picture was very different in the past across a broad latitudinal band that extends from NW Mexico to Vancouver Island. Ganeshram et al. [1995] and others [Cannariato and Kennett, 1999; McKay et al., 2004; Ortiz et al., 2004], have variously concluded that subsurface ventilation, and/or upwelling and export production, and by inference primary production, varied markedly both locally and regionally along the margin during the late Quaternary.

\footnotetext{
${ }^{1}$ Department of Geological Sciences, University of Michigan, Ann Arbor, Michigan, USA.

${ }^{2}$ School of Earth and Ocean Sciences, University of Victoria, Victoria, BC, Canada.

${ }^{3}$ Department of Geological Sciences and Marine Science Institute, University of California, Santa Barbara, California, USA.

${ }^{4}$ Geological Institute, University of Tokyo, Tokyo, Japan.

Copyright 2004 by the American Geophysical Union. 0883-8305/04/2003PA000965
}

[3] Such studies have considerably advanced understanding of physical and biological dynamics temporally along the western marine margin of North America. However, there remains a need to distinguish variations in sedimentary organic carbon concentration associated with euphotic zone productivity from that due to the effect of changes on the subsurface oxygen inventories. Variability in either or both of these parameters occurred with century- to millennial-scale frequency during MIS 3, and have been shown to correlate closely at the individual event level with climate changes in the North Atlantic region [Behl, 1995; Cannariato and Kennett, 1999; Cannariato et al., 1999; McKay et al., 2004; Ortiz et al., 2004]. The first step toward distinguishing euphotic zone productivity from subsurface water mass ventilation requires a complete understanding of the biotic response to climate variations in an upwelling region. Understanding the relationship between submillennial climate change and productivity on the California Margin will improve our ability to evaluate the relative contribution of organic carbon delivery versus subsurface ventilation on North Pacific Intermediate Waters. Furthermore, it has been shown that greenhouse gases $\left(\mathrm{CO}_{2}\right.$ and $\left.\mathrm{N}_{2} \mathrm{O}\right)$ that can be related to upwelling also varied on submillennial timescales [Fluckiger et al., 2004], thus understanding the relationship between such amplifiers of climate change and the history of upwelling off California is imperative.

[4] Ocean Drilling Program (ODP) Hole 1017E was drilled on the southern slope of the Santa Lucia Bank $\left(34^{\circ} 32^{\prime} \mathrm{N} ; 121^{\circ} 6^{\prime} \mathrm{W}\right)$ in $955 \mathrm{~m}$ of water, $\sim 50 \mathrm{~km}$ west of 


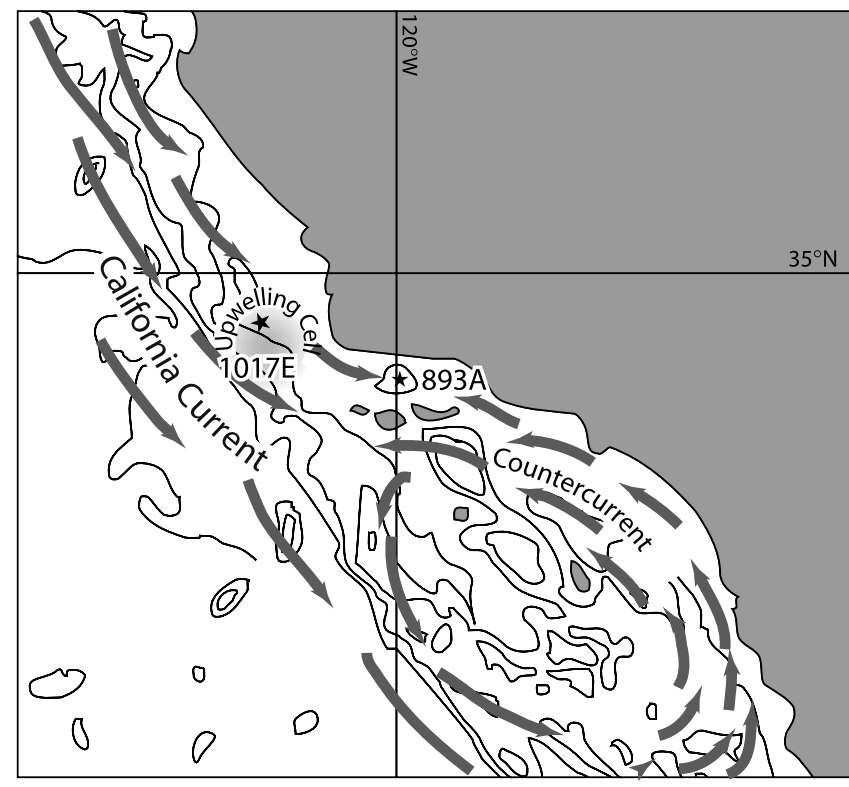

Figure 1. Map showing the location of Ocean Drilling Program (ODP) Site 1017E (San Lucia Slope) and ODP Hole 893A (Santa Barbara Basin). Also shown are the surface ocean currents on the Southern California continental margin that influence the region.

Point Conception and Arguello. This site lies beneath a persistent modern upwelling cell and has been shown to yield high-resolution records of paleoceanographic change (Figure 1; Cannariato and Kennett [1999], Irino and Pedersen [2000], Kennett et al. [2000], Tada et al. [2000]). Consequently, this hole provides an excellent opportunity to study the paleoproductivity history of the open southern California Margin. Today, nutrient-rich, cool water that wells up off Point Conception is advected into the Santa Barbara Basin where excellent records of rapid submillennial-scale climate change have been described [Behl and Kennett, 1996; Hendy and Kennett, 1999; Ivanochko and Pedersen, 2004] As a result, understanding upwelling and surface water nutrient history at ODP Hole 1017E is also crucial for interpreting the biogenic sediments of the Santa Barbara Basin paleoceanographic record.

[5] A variety of geochemical tracers and micropaleontological proxy indicators were employed to explore, with high resolution, the history of export production off southern California during the last 60,000 years. These tracers include; bulk sedimentary organic carbon, carbonate, major and minor element concentrations, $\delta^{15} \mathrm{~N}$ measurements, $\delta^{13} \mathrm{C}$ analyses of planktonic foraminifera, and planktonic foraminiferal species-census data. It will be shown that intervals of high productivity were related to climatically induced changes in upwelling intensity. Furthermore, certain productivity events were associated with different planktonic phytoplankton and zooplankton assemblages that mark responses to the changing nutrient content of subsurface water masses. Finally we suggest the upwelling cell was affected by changing wind strength and direction, and the presence of the California Undercurrent.

\section{Methods}

[6] Samples were taken every $3 \mathrm{~cm}$ from ODP Hole 1017E. Aliquots for microfaunal analysis were processed using standard techniques [Kennett, 1995]). Stable isotope measurements were made on samples of the surface dwelling planktonic foraminifera Globigerina bulloides and the thermocline dwelling Neogloboquadrina pachyderma [Kincaid et al., 2000; Pak and Kennett, 1997, 2002] collected from 408 samples between 0.12 and $12.23 \mathrm{~m}$ subbottom depth (msbd). Between 8 and 40 planktonic foraminifera were picked for each stable isotopic analysis, which was performed on a Finnigan/MAT 251 mass spectrometer following standard preparation techniques. Instrumental precision was $<0.09 \%$ for both isotopes; all data are expressed as standard delta notation in per mil relative to the Peedee belemnite standard, related by repeated analysis of NBS-19 and NBS-20 [Coplen, 1997].

[7] A high-resolution planktonic foraminiferal assemblage record in Hole 1017E was generated from 350 samples from 2.1 to $12.21 \mathrm{msbd}$. Faunal counts were based on $\sim 300$ specimens in the $>150 \mu \mathrm{m}$ sediment size fraction. Relative abundance is presented as the percentage contribution of each species to the census. The foraminiferal flux rate is presented here as the number of specimens contained in $1 \mathrm{~cm}^{3}$ of sample per year. Following standard procedure, coiling variants of $N$. pachyderma were counted individually. Thus the ratio of sinistral to dextral $N$. pachyderma specimens is presented as well as the relative abundance of each morphotype.

[8] Concentrations of major and minor elements were determined for 337 samples from 5.9 to $15.4 \mathrm{msbd}$, using the method of Calvert et al. [1985] and a Phillips PW 2400 $\mathrm{X}$-ray spectrometer equipped with a $\mathrm{Rh}$ tube operated at $3 \mathrm{~kW}$. Nitrogen isotope ratios were determined for 493 samples from 0 to $14.38 \mathrm{msbd}$ using an elemental analyzer directly coupled to a VG Prism mass spectrometer, as described by Ganeshram et al. [1995]. Analytical precision based on internal acetanilide standards was better than $0.2 \%$. The $\delta^{15} \mathrm{~N}$ values are reported relative to air. Salt content $(\% \mathrm{Cl})$ was determined volumetrically by Knudsentype titration [Strickland and Parsons, 1972] using $\mathrm{AgNO}_{3}$ solution with $\mathrm{K}_{2} \mathrm{CrO}_{4}$ color indicator.

[9] Biogenic silica was determined on 430 samples between 0 and $12.4 \mathrm{msbd}$ using the methods of Mortlock and Froelich [1989] with some modifications. Care was taken to use only $20 \mathrm{mg}( \pm 0.9 \mathrm{mg})$. Known samples from Jervis and Saanich inlets (British Columbia) were used as standards and 14 repeated analyses yielded concentrations of $30.35( \pm 1.84)$ and $13.41( \pm 1.09)$ percent biogenic silica respectively. Owing to low biogenic silica concentrations in the sediments of ODP Hole 1017E, each digested sample was pipetted twice (standard deviation of $0.5 \%$ ) and averaged to reduce error.

\section{Chronology}

[10] The chronology used in this investigation improves on that of Kennett et al. [2000], reflecting the inclusion of 
Table 1. Raw and Calibrated ${ }^{14} \mathrm{C}$ Dates With Uncertainties ${ }^{\mathrm{a}}$

\begin{tabular}{|c|c|c|c|c|c|c|c|c|}
\hline $\begin{array}{l}\text { Core } \\
\text { Section } \\
\end{array}$ & $\begin{array}{l}\text { Sample } \\
\text { Interval }\end{array}$ & $\begin{array}{c}\text { Age, }{ }^{14} \mathrm{C} \\
\text { years } \\
\end{array}$ & \pm & $\begin{array}{l}1 \text { Sigma Maximum } \\
\text { Calendar Age Range }\end{array}$ & $\begin{array}{c}\text { Calendar } \\
\text { Ages }\end{array}$ & $\begin{array}{l}\text { 1 Sigma Minimum } \\
\text { Calendar Age Range }\end{array}$ & $\begin{array}{c}\text { Depth, } \\
\text { void-corrected mbsf }\end{array}$ & $\begin{array}{c}\text { Data, } \\
\text { calendar years }\end{array}$ \\
\hline $1 \mathrm{H}-2$ & $54-57$ & 8500 & 100 & 8598 & 8805 & 8913 & 1.97 & 8810 \\
\hline $1 \mathrm{H}-2$ & $63-66$ & 9010 & 50 & 9049 & 9223 & 9597 & 2.05 & 9220 \\
\hline $1 \mathrm{H}-2$ & $132-135$ & 11880 & 50 & 13,009 & 13,145 & 13,734 & 2.72 & 13,150 \\
\hline $1 \mathrm{H}-2$ & $135-138$ & 10960 & 90 & 11,670 & 11,945 & 12,320 & & \\
\hline $1 \mathrm{H}-3$ & $0-3$ & 12900 & 50 & 14,085 & 14,122 & 14,322 & 2.89 & 14,120 \\
\hline $1 \mathrm{H}-3$ & $12-15$ & 13050 & 60 & 14,131 & 14,303 & 15,184 & 3.00 & $14,660^{\mathrm{c}}$ \\
\hline $1 \mathrm{H}-3$ & $33-36$ & 16280 & 60 & 18,281 & 18,570 & 18,879 & & \\
\hline $1 \mathrm{H}-3$ & $51-54$ & 14930 & 60 & 16,765 & 17,016 & 17,280 & 3.38 & 17,020 \\
\hline $1 \mathrm{H}-3$ & $69-72$ & 15540 & 80 & 17,445 & 17,718 & 18,007 & 3.55 & 17,720 \\
\hline $1 \mathrm{H}-3$ & $111-114$ & 16660 & 70 & 18,703 & 19,007 & 19,328 & 3.95 & 19,010 \\
\hline $1 \mathrm{H}-3$ & $126-129$ & 17190 & 80 & 19,295 & 19,617 & 19,951 & 4.09 & 19,620 \\
\hline $1 \mathrm{H}-4$ & $12-15$ & 17670 & 100 & 19,832 & 20,169 & 20,515 & 4.44 & 20,170 \\
\hline $1 \mathrm{H}-4$ & $39-42$ & 18730 & 120 & 21,032 & 21,389 & 21,758 & 4.70 & 21,390 \\
\hline $2 \mathrm{H}-1$ & $18-21$ & 24960 & 200 & & 28,584 & & & \\
\hline $2 \mathrm{H}-2$ & $18-21$ & 29040 & 380 & & 33,197 & & & \\
\hline
\end{tabular}

${ }^{\mathrm{a}}$ From E. B. Roark et al. (manuscript in preparation, 2004). Also listed are the final depths and calibrated ages used for the linear interpolation from 10 to $30 \mathrm{ka}$.

${ }^{b}$ Void corrected depth from Kennett et al. [2000].

${ }^{\mathrm{c}}$ Averaged upper and lower sigma 1 error range age used in determination of datum.

several additional radiocarbon age datums. In addition, it is assumed here that the foraminiferal assemblages responded to climate forcing regionally [Hendy, 2000], and this assumption allows interhole correlation within the Southern Californian Bight for MIS 3. The age model for Hole 1017E is based on 11 calendar year [Stuiver et al., 1998] calibrated ${ }^{14} \mathrm{C}$ dates (E. B. Roark et al., manuscript in preparation, 2004) across the upper $4.70 \mathrm{~m}$ of the hole (Table 1) and linear interpolation of six climatic event datums beyond $30 \mathrm{ka}$ (Table 2). These event horizons are based on correlation between ODP Hole 893A and 1017E N. pachyderma coiling ratios [Hendy, 2000] and are supported by alkenone temperature estimates [Seki et al., 2002] and planktonic $\delta^{18} \mathrm{O}$ [Kennett et al., 2000]. The chronology of ODP Hole 893A is described in detail in the work of Hendy et al. [2002]. It is assumed in the Hole 893A age model that interstadials (IS) 5-17 are synchronous with interstadial events in the Greenland ice cores.

\section{Results}

\subsection{Planktonic Foraminiferal Assemblages}

[11] Planktonic foraminiferal assemblages can be used to identify a number of different surface water environmental conditions including temperature range, nutrient availability and phytoplankton communities. Assemblages are presented three different ways in this contribution (relative and absolute abundances, and as ratios). The ratio of right coiling (dextral) to left coiling (sinistral) N. pachyderma
(Figure 2a) clearly defines warm climatic events of the last glacial, also defined by planktonic $\delta^{18} \mathrm{O}$ [Kennett et al., 2000] and alkenones [Seki et al., 2002]. The dominantly dextral, reticulate morphotype of $N$. pachyderma is found at or below the thermocline in $8^{\circ}$ to $14^{\circ} \mathrm{C}$ waters [Reynolds and Thunell, 1986]. Sinistral N. pachyderma is not presently found in Southern Californian surface water [Sautter and Thunell, 1991]. This species inhabits cool waters between $6^{\circ}$ and $8^{\circ} \mathrm{C}$ at $50^{\circ} \mathrm{N}$ [Reynolds and Thunell, 1986], although it has been found in surface waters as warm as $10^{\circ} \mathrm{C}$ off southern Oregon, in association with seasonal upwelling and increased transport of subarctic water in the California Current [Ortiz and Mix, 1992].

[12] The variations seen in the coiling ratio profile for Hole $1017 \mathrm{E}$ are very similar to those found south of the site at ODP Hole 893A and ODP Site 1014 [Heider et al., 2001; Hendy, 2000; Hendy and Kennett, 2000]. These represent warming at interstadial events (except IS 3, which was not recovered in 1017E due to a coring gap) and are used to define shifts between stadial and interstadial events at the site. Termination 1a is sharply defined as a rapid rise in the ratio at $\sim 14.7 \mathrm{ka}$, while the Bølling has a slightly lower ratio than the Allerød. The Younger Dryas is defined by a decline in the ratio. The apparent young age of the Younger Dryas is probably due to poorly constrained chronostratigraphy in this section of the record.

[13] The relative abundance (percent of total abundance) of two planktonic foraminiferal species associated with upwelling is shown in Figure 2, as is their absolute

Table 2. Depths of Rapid Climate Change Events Identified in ODP Hole 1017E and the Calendar Year Ages Identified in GISP2

\begin{tabular}{lcccc}
\hline Interstadial Data & Core Section & Sample Interval & Depth, ${ }^{a}$ void-corrected mbsf & Age, calendar years \\
\hline IS event 8 start & $2 \mathrm{H}-2$ & $45-48$ & 7.70 & 38,400 \\
IS event 11 start & $2 \mathrm{H}-3$ & $21-24$ & 8.85 & 42,600 \\
IS event 12 start & $2 \mathrm{H}-3$ & $102-105$ & 9.59 & 45,400 \\
IS event 14 start & $2 \mathrm{H}-4$ & $81-84$ & 10.77 & 52,200 \\
IS event 17 start & $2 \mathrm{H}-5$ & $57-60$ & 11.92 & 58,300 \\
MIS 3/4 boundary & $2 \mathrm{H}-5$ & $108-111$ & 12.39 & 64,090 \\
\hline
\end{tabular}

${ }^{\mathrm{a}}$ Void-corrected depth from Kennett et al. [2000]. 


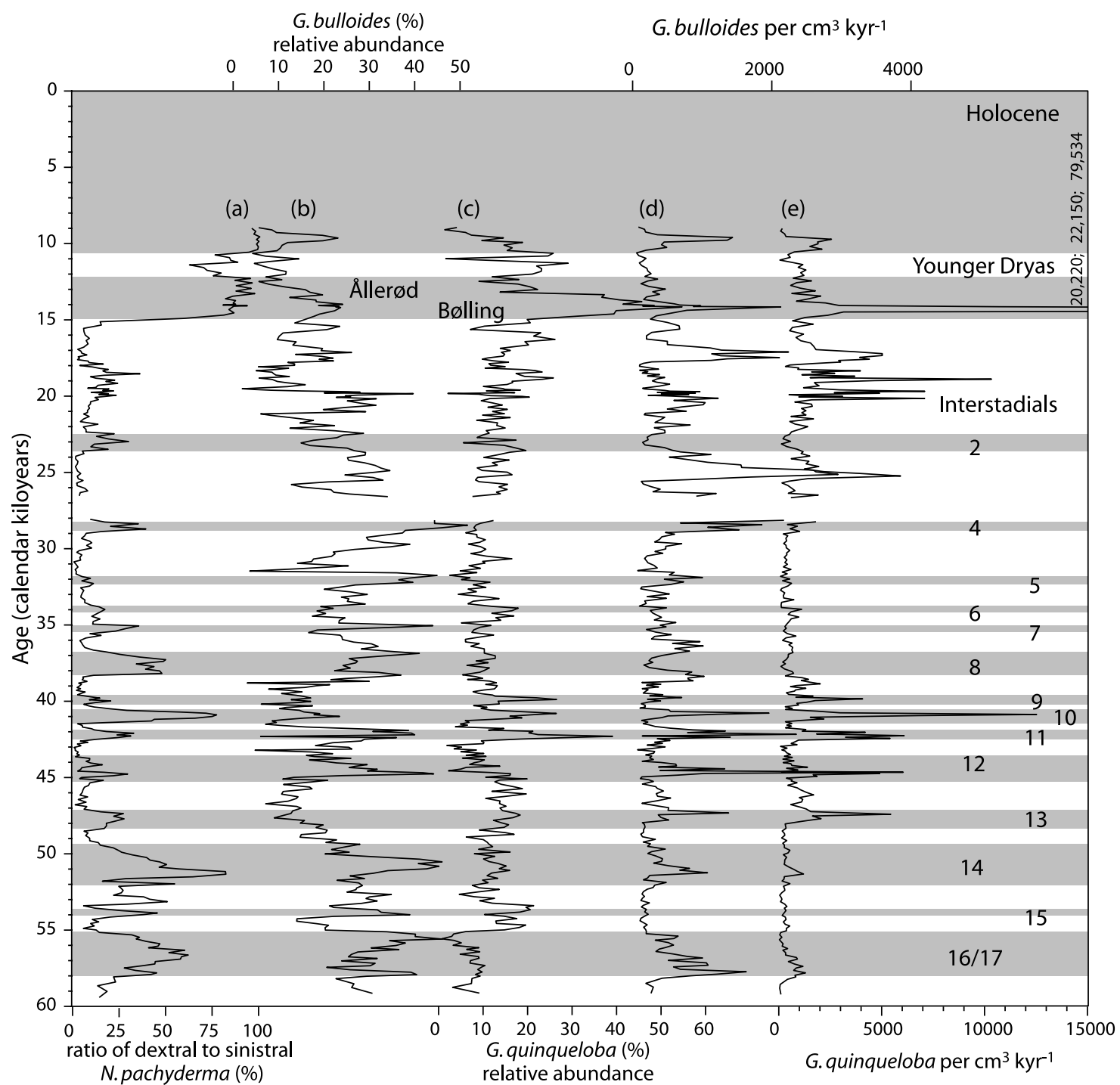

Figure 2. Comparison of planktonic foraminiferal faunal records of (a) the ratio (\%) of dextral to sinistral N. pachyderma; the relative abundances (\%) of (b) G. bulloides and (c) G. quinqueloba; and the absolute abundances (specimens per $\mathrm{cm}^{3} \mathrm{kyr}^{-1}$ ) of (d) G. bulloides and (e) G. quinqueloba. Gray bands represent warm intervals (interstadials and the Holocene). Interstadials (D-O events) are numbered according to GISP2 scheme.

abundances in whole shells per $\mathrm{cm}^{3} \mathrm{kyr}^{-1}$. Relative abundance compares the variation in planktonic species associated with upwelling versus those primarily responding to sea surface temperature. G. bulloides is a eurythermal species typically found in the surface mixed layer of waters ranging in temperature between $6^{\circ}$ and $26^{\circ} \mathrm{C}$. This species is most dominant in cool subtropical/transitional upwelling conditions [Sautter and Thunell, 1991]. The relative abundance of $G$. bulloides varies between 10 and $50 \%$ during the last glacial. Increases in abundance to between 30 and $40 \%$ occur at interstadial events (Figure 2b). A small increase occurs during the Bølling with reductions to lower values during the Allerød and the Younger-Dryas. Globigerina quinqueloba, another eurythermal species, occurs in surface mixed layer waters that range in temperature from $5^{\circ}$ to $20^{\circ} \mathrm{C}$. This species has been observed to increase in abundance during spring and diatom blooms [Sautter and Thunell, 1991]. The relative abundance of G. quinqueloba remains between 10 and $20 \%$ throughout most of the last glacial, except during IS 11, 10, 9 and the Bølling when the relative abundance jumps to $30-60 \%$ (Figure $2 \mathrm{c}$ ).

[14] Absolute abundance is used in this contribution to display the occurrence of extremely high numbers of individual specimens in response to abundant food availability. The absolute abundance of $G$. bulloides increases by as much as 10-fold downcore for brief intervals independent of the age model. These events generally coincide with interstadials, however during the Last Glacial Maximum, they also correspond to intervals of enhanced coccolith and biogenic silica concentrations but not increased SSTs (Figure 2d). All planktonic foraminiferal faunal assemblage records end at $\sim 9 \mathrm{ka}$ when dissolution of 
carbonate became severe resulting in an order magnitude decrease in specimen number, a decrease in assemblage diversity, and domination of the assemblage by dissolution resistant sinistral $N$. pachyderma and other more resistant warm fauna (i.e., Orbulina universa). In contrast to the severe fragmentation of some specimens seen in the post 9 ka deposits, glacial-age specimens appear well preserved.

\subsection{Carbonate Abundance}

[15] Percent carbonate in hemipelagic sediments typically provides an indication of the relative contribution of carbonate producing organisms to mass accumulation rates. It therefore can be a crude indicator of carbonate productivity. Carbonate \% peaks correspond in Hole 1017E to increases in both coccolith abundance [Tanaka and Tada, 2000] and planktonic foraminiferal absolute abundance (Figures $3 \mathrm{a}$ and $3 \mathrm{c}$ ). Percent carbonate increases during interstadial events, the Bølling and the early Holocene (Figure 3a). Planktonic foraminiferal abundance increases simultaneously during the same interstadial events mentioned above (Figures $4 \mathrm{a}$ and $4 \mathrm{~b}$ ); however the dramatic G. bulloides abundance increases seen in MIS 2 are not reflected in \% carbonate (Figures 3a and 3c). Coccolith abundance and \% carbonate show a dramatic increase in the early Holocene that tapers off by the mid-Holocene (Figures $3 \mathrm{a}$ and $3 \mathrm{~b}$ ).

\subsection{Percent Biogenic Opal}

[16] Biogenic silica $\left(\mathrm{Si}_{\mathrm{bio}}\right)$ is measured as the percent opal concentration of sediments and represents the relative contribution of silica producing organisms (diatoms and radiolaria) to mass accumulation. Therefore percent opal is often used as an indicator of diatom productivity. Opal concentrations at ODP Hole 1017E are low throughout the last $60 \mathrm{ka}$ (Figure 4c), which presents difficulties when interpreting results. Analyses were repeated where large opal concentration changes occurred downcore in order to ensure reproducibility. Reproducible peaks in opal concentration occur between 15 and $10 \mathrm{ka}$, at $25 \mathrm{ka}$ and between 48 and $40 \mathrm{ka}$ (Figure 4c). With such low concentrations of opal, the strong possibility remains that the analytical results do not reflect diatom concentrations, but rather a record of amorphous $\mathrm{Al} / \mathrm{Si}$ coatings on particles or authigenic clay minerals that precipitate from silicic acid released during siliceous microfossil dissolution.

\section{4. $\delta^{15}$ Nitrogen}

[17] Downcore bulk sedimentary nitrogen isotopes may be used at ODP Hole 1017E as water mass indicator. The California Margin is a nitrate limited region and therefore particulate nitrogen that settles in sediments records the $\delta^{15} \mathrm{~N}$ of local surface water nitrate [Altabet et al., 1999] while diagenetic effects are minimal [Ganeshram et al., 2000]. The global ocean $\delta^{15} \mathrm{~N}$ average is estimated to be around 4.5-5\%o [Sigman et al., 1997] while the average $\delta^{15} \mathrm{~N}$ from modern California Borderland sediments is 7.88.4\%o [Liu and Kaplan, 1989]. Nitrate measured in the water column of San Pedro Basin to the south, recorded values of $\sim 8 \%$ at $100 \mathrm{~m}$ increasing to $\sim 12 \%$ at $300 \mathrm{~m}$ water depth [Liu and Kaplan, 1989]. Presently isotopically heavy nitrate $(18 \%$; Liu and Kaplan [1989]) is produced in the
Eastern Tropical Pacific, between 200 and 400 meters depth in the water column by denitrification [Brandes et al., 1998]. It is transported to surface waters by upwelling, and subsequently taken up by phytoplankton. Settling of phytoplankton remains through the water column transmits the isotopic signal to the seafloor [Altabet et al., 1999].

[18] The $\delta^{15} \mathrm{~N}$ of particulate nitrogen at DP Hole $1017 \mathrm{E}$ shows a general increase during interstadial events (Figure 4e). The increase in $\delta^{15} \mathrm{~N}$ of particulate nitrogen from the last glacial to the Holocene begins between 17 and $16 \mathrm{ka}$, with the most significant increase of the record occurring rapidly at the initiation of the Bølling. $\delta^{15} \mathrm{~N}$ decreases to intermediate values during the Allerød and Younger Dryas, increasing again 500 years after the beginning of the Preboreal. The regional context of the $\delta^{15} \mathrm{~N}$ record from ODP Hole 1017E is discussed in greater detail in the work of Kienast et al. [2002].

\subsection{Planktonic $\delta^{13}$ Carbon}

[19] The carbon isotopic composition of $\Sigma \mathrm{CO}_{2}$ decreases with depth in the ocean as a result of organic material degradation (discussed further in section 5.1.2). Subsurface water initially returned to the surface has a low $\delta^{13} \mathrm{C}$ signature, and therefore low planktonic foraminiferal $\delta^{13} \mathrm{C}$ values may be associated with upwelled water masses. Carbon isotope analyses were performed on two species of planktonic foraminifera, surface dwelling G. bulloides and thermocline dwelling $N$. pachyderma. Significant decreases in $\delta^{13} \mathrm{C}(\sim 1 \%)$ occur at nearly every interstadial event during MIS 3 (Figure 3e). These decreases often coincide with $\delta^{15} \mathrm{~N}$ increases (Figure 4), and are synchronous with increases in the absolute abundance of G. bulloides during MIS 3 (Figures $3 \mathrm{c}$ and $3 \mathrm{~d}$ ). This relationship between absolute abundance and ${ }^{13} \mathrm{C}$ values disappears during MIS 2, when there is a steady increase in $\delta^{13} \mathrm{C}$ values in both planktonic species.

\subsection{Organic Carbon}

[20] The organic carbon distribution down-hole varied between 3 and 0.3 wt.\% (Figure 5c; Irino and Pedersen [2000]). General increases in organic carbon occur during interstadial events. Large decreases in organic carbon $\%$ during MIS 2 are related to small sand layers. Organic carbon sharply increases to $2.5 \%$ at the Bølling, but returns to concentrations similar to the Last Glacial Maximum during the Allerød and Younger Dryas. At the beginning of the Holocene, organic carbon increases again to $\sim 2 \%$, with a steady increase during the Holocene toward the present possibly as a result of burndown.

\subsection{Major and Minor Elements}

[21] Major and minor elements are presented here due to their close correlation with \% organic carbon. For simplification of the data set a $\mathrm{Q}$ mode factor analysis with varimax rotation of selected major and minor elements was undertaken using the computer program CABFAC [Imbrie and Kipp, 1971]. The objective of creating a Q mode factor model is to explain interrelationships in a multivariate database by the presence of a few factors that reveal the simple underlying structure. Two factors explaining $97.3 \%$ of the total variance were extracted from 


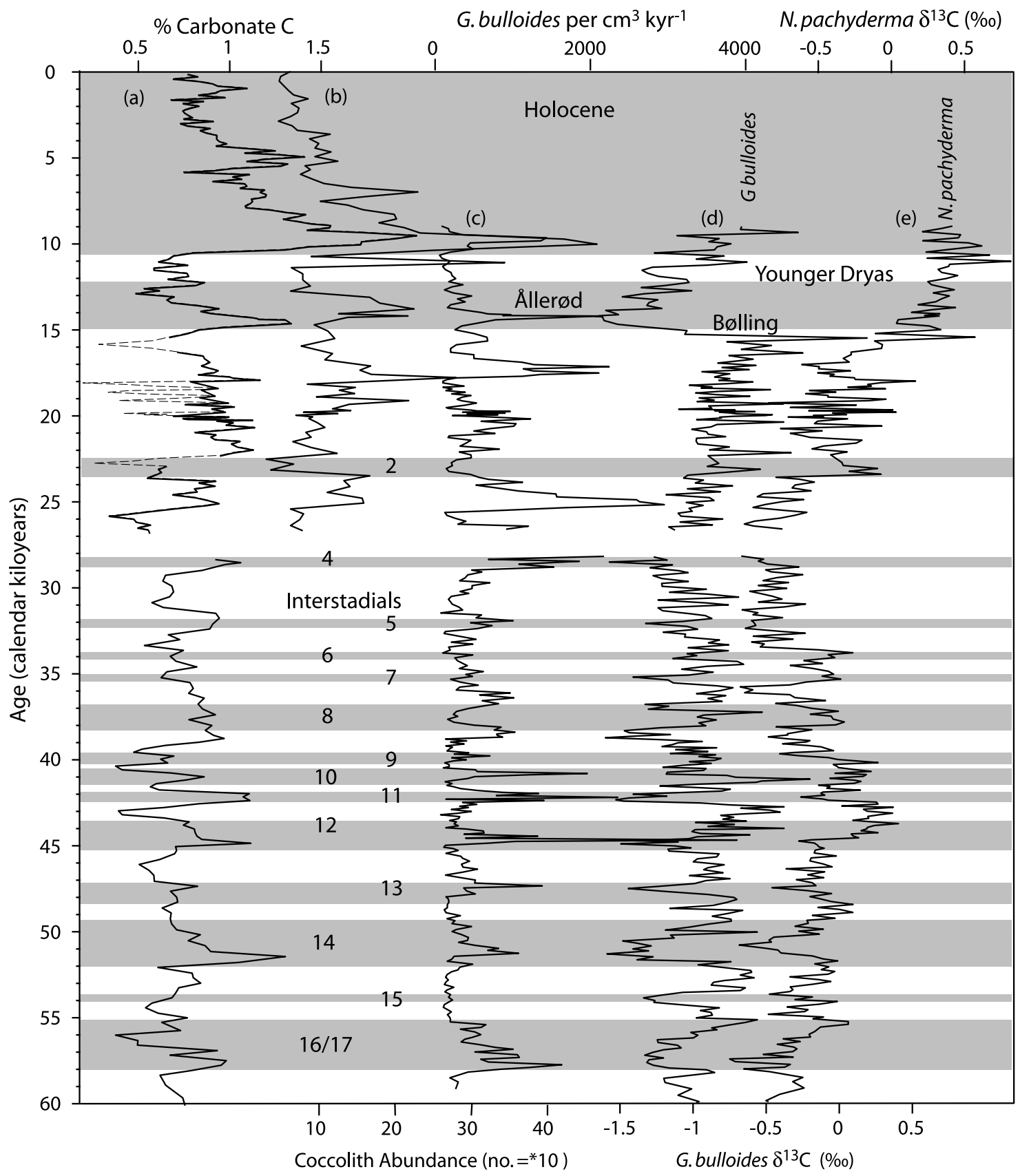

Figure 3. Comparison of proxy records associated with carbonate precipitating plankton. (a) Percent carbonate composition of the sediments; (b) absolute abundance of coccoliths $(\times 10)$ [Tanaka and Tada, 2000]; (c) absolute abundance (specimens per $\mathrm{cm}^{3} \mathrm{kyr}^{-1}$ ) of $G$. bulloides; the $\delta^{13} \mathrm{C}$ (\%) record of (d) G. bulloides; and (e) N. pachyderma. Gray bands represent warm intervals (interstadials and the Holocene). Interstadials (D-O events) are numbered according to GISP2 scheme.

the data set that included $\mathrm{Ni}, \mathrm{Cu}, \mathrm{Zn}, \mathrm{Zr}, \mathrm{Mn}, \mathrm{Si}, \mathrm{Al}, \mathrm{Fe}, \mathrm{Mg}$, $\mathrm{Ca}, \mathrm{Na}$, and $\mathrm{K}$ (Table 3). Communalities are mostly $>0.95$ showing factor groupings well describe the data set.

[22] The factors are as follows: Loading in factor $1(54.4 \%$ of total variance) is dominated by $\mathrm{Ni}, \mathrm{Cu}, \mathrm{Zn}$, $\mathrm{Fe}, \mathrm{Mg}$ and $\mathrm{Ca}$. We associate factor 1 with the clay fraction. Generally increases in factor 1 occur during interstadial events, the Bølling and the Holocene. Factor 2 (42.9\% of the total variance) loadings are influenced by $\mathrm{Zr}, \mathrm{Si}, \mathrm{Na}$, and
$\mathrm{K}$. We associate factor 2 with the silt and sand fraction. Increases in this factor occur during cool intervals of the last glacial as well as during the Ållerød and Younger Dryas.

\section{Discussion}

[23] The multiproxy geochemical and micropaleontological records from ODP Hole 1017E provide a unique opportunity to resolve whether the semipermanent upwelling cell 


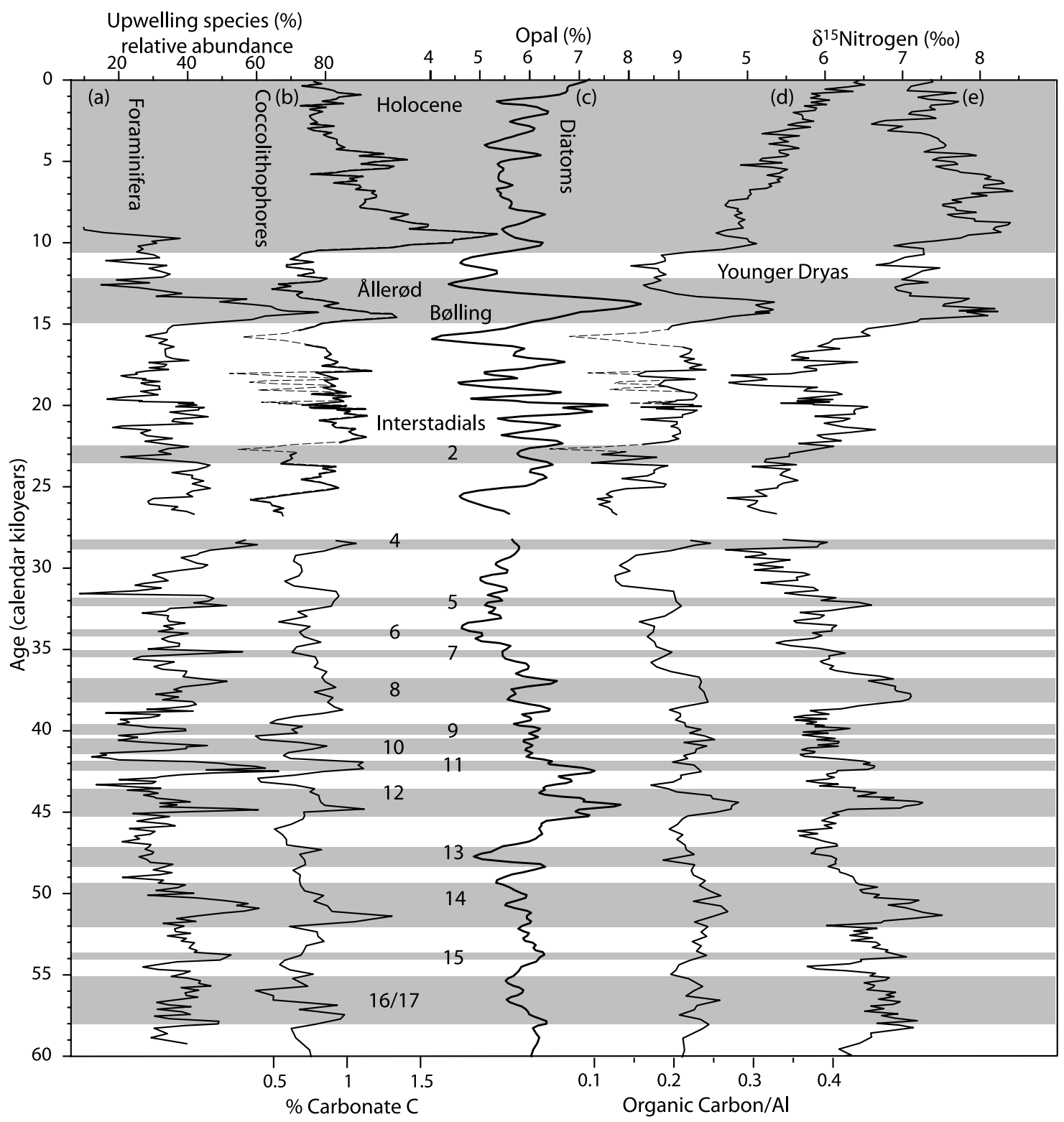

Figure 4. Comparison of proxy records associated with phytoplankton and zooplankton. (a) The relative abundance (\%) of upwelling associated species G. quinqueloba and G. bulloides; (b) percent (\%) carbonate composition of the sediments; (c) percent $(\%)$ opal $_{(\text {diatom) }}$ composition of the sediments; (d) organic carbon to $\mathrm{Al}$ weight ratio of the sediments; and (e) the $\delta^{15} \mathrm{~N}$ composition of the sediments. Gray bands represent warm intervals (interstadials and the Holocene). Interstadials (D-O events) are numbered according to GISP2 scheme.

off Point Conception responded to climate forcing during the late Quaternary. As discussed in the following section, the new data suggest that changes in productivity indeed occurred, and these resulted from a complex interplay between far-field and local processes.

\subsection{Response of Export Production to Climate Change}

\subsubsection{Organic Matter Deposition: Grain Size or Productivity-Controlled?}

[24] Major and minor element distributions and their association with grain size at ODP Hole 1017E have previously been discussed by Tada et al. [2000] and Irino and Pedersen [2000]. Tada et al. [2000] found that relative variations in $\mathrm{Zr}, \mathrm{Si}, \mathrm{Na}$, and $\mathrm{K}$ concentrations (discussed on a salt-free basis) were associated with changes in the proportions of the silt and sand-sized fractions. The abundance of these elements reflect their association with quartz and $\mathrm{K}$ feldspar which are dominant constituents of sand and silt size fractions, as well as the relative enrichment of zircon in coarser grain sizes. In contrast, $\mathrm{Ni}, \mathrm{Cu}, \mathrm{Zn}, \mathrm{Fe}, \mathrm{Mg}$ and $\mathrm{Ca}$ concentrations are associated with the clay-sized grain fraction. Organic carbon concentrations correlate strongly (Figures $2 \mathrm{~b}$ and $2 \mathrm{c} ; \mathrm{r}^{2}=0.63$ ) with relative 


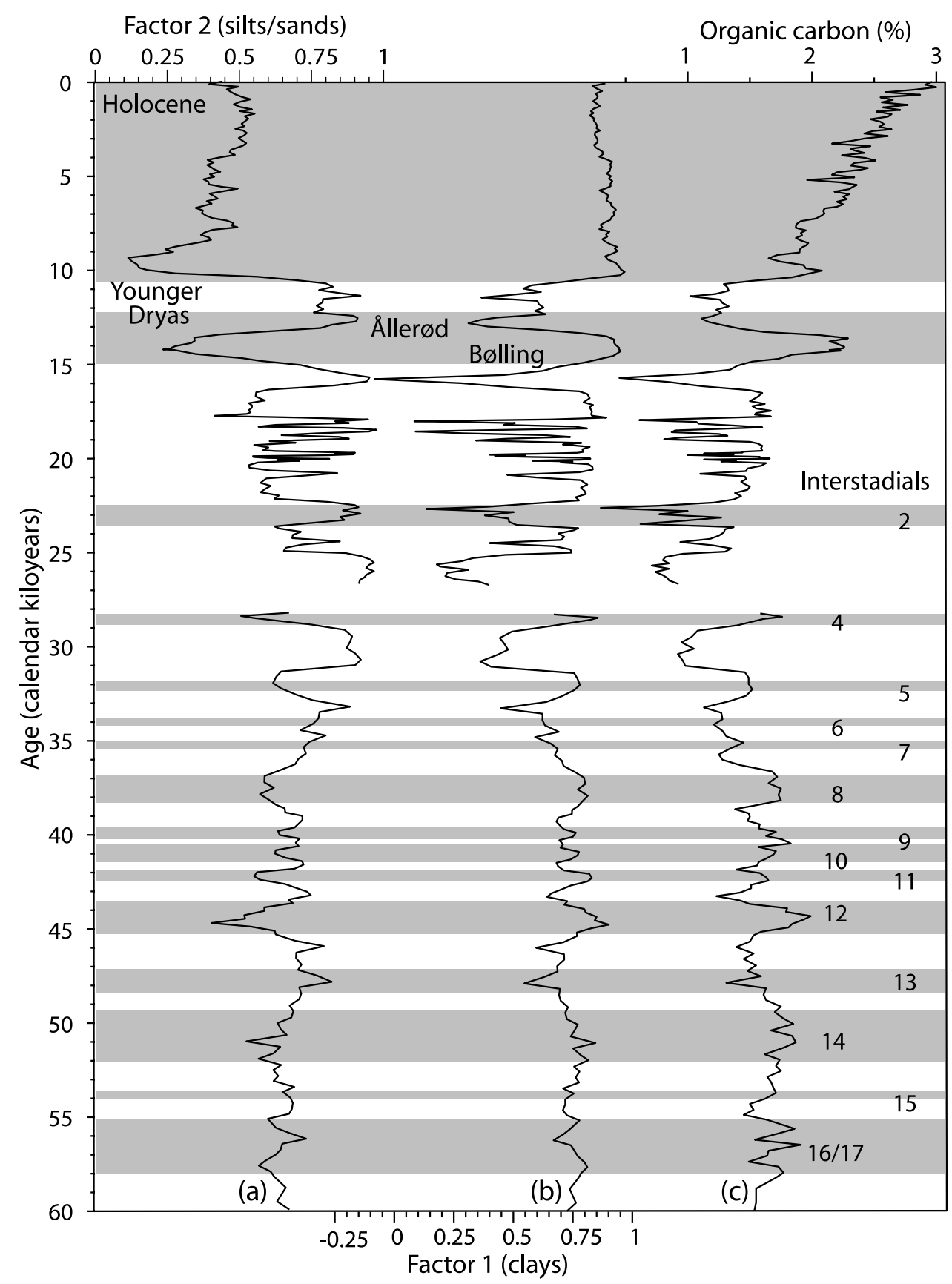

Figure 5. Comparison of factors produced $\mathrm{Q}$ mode factor analysis with varimax rotation of selected major and minor elements [Imbrie and Kipp, 1971] with (c) percent organic carbon. (a) Factor 1 is dominated by $\mathrm{Si}, \mathrm{Zr}, \mathrm{Na}$, and $\mathrm{K}$ (silts to sands), while (b) factor 2 is loaded with $\mathrm{Ni}, \mathrm{Cu}, \mathrm{Zn}, \mathrm{Fe}, \mathrm{Mg}$ and $\mathrm{Ca}$ (clays). Gray bands represent warm intervals (interstadials and the Holocene). Interstadials (D-O events) are numbered according to GISP2 scheme.

abundances of these elements reflected in factor 2, suggesting a close association between small grain size and organic matter content. Such a relationship has been long acknowledged, with organic material being typically concentrated in fine-grained sediments [Hedges and Keil, 1995]. This has been attributed to a variety of processes including: (1) hydrodynamic sorting that similarly affects fine minerals and organic particles that are larger but of lower density [Tyson, 1987]; (2) sorption of organic material onto the surfaces of fine particles. Collectively these present an abundant area for adsorption [Seuss, 1973]; and (3) interaction of marine snow with nepheloid layers below upwelling sites [Ransom et al., 1998]. Each option is assessed below.

[25] Hydrodynamic sorting was discussed by Tada et al. [2000], who used an observed millennial-scale variability in grain size to suggest that shear velocities at the ocean floor changed in association with climate variations. Increased 
Table 3. Varimax Factor Scores for 12 Major and Minor Elements at ODP Hole 1017E

\begin{tabular}{lll}
\hline Variable & Factor 1 & Factor 2 \\
\hline Nickel & 1.0091 & -0.0034 \\
Copper & 1.574 & -0.1021 \\
Zinc & 1.3846 & -0.1566 \\
Zircon & -0.3609 & 1.1535 \\
Manganese & 0.6318 & 0.7897 \\
Silica & -0.3407 & 1.698 \\
Aluminum & 0.6096 & 0.8667 \\
Iron & 1.3843 & 0.3503 \\
Magnesium & 1.4538 & 0.4504 \\
Calcium & 1.2119 & -0.1955 \\
Sodium & -0.0657 & 1.777 \\
Potassium & -0.259 & 1.6896 \\
\hline
\end{tabular}

bottom current strengths were inferred for cooler intervals of the last glacial [Tada et al., 2000], coinciding with increased ventilation (or higher dissolved oxygen input; Cannariato and Kennett [1999]) and cooling [Hendy and Kennett, 2003] of intermediate waters. Increased southward flow of fresh, cool, high oxygen intermediate waters during stadials may have winnowed out the fine-sediment size fraction, thus depleting organic matter. An opposite lower velocity flow of oxygen-depleted water from the northeast equatorial Pacific during interstadials would have had the reverse effect. The second option affirms that almost all marine sedimentary organic matter is sorbed onto mineral surfaces and consequently concentrated in fine-grained sediments with large surface areas. This hypothesis would imply that processes controlling grain size were fundamental in producing the organic carbon record of Hole 1017E.

[26] The third possibility relates to marine snow (aggregates with diameters greater than $5 \mathrm{~mm}$ ), which is now known to be important for organic matter transportation through the water column in upwelling regions [Alldredge et al., 1993]. Recent studies off Point Conception have shown that loose networks of aggregates presently exist in the upper water column. These consist of extracellular mucopolysaccharides, bioclasts (foraminiferal tests and diatom frustules), primary organic detritus and microbes [Ransom et al., 1998]. Similar aggregates collected in the near-seafloor nepheloid layer contained clay particles, clay flocs, and relatively dense clay organic-rich microaggregates [Ransom et al., 1998]. The prevalence of the latter suggests that prior to deposition and burial, marine snow is subject to disaggregation and recombination with terrigenous detrital material near or at the seafloor resulting in the flocculation of clay particles.

[27] Floc-rich nepheloid layers are dynamic and ubiquitous phenomena that occur on continental slopes. Though their occurrence is temporally and spatially variable, associations with upwelling regions are well known. On the San Pedro shelf, suspended sediment patterns are associated with upwelling and/or the intrusion of cold water from the north [Gorsline, 1984]. Large rings and eddies (diameters of $100-200 \mathrm{~km}$ ) can extend to $1500 \mathrm{~m}$ depth in the California Current system [Gorsline, 1984; Koblinsky et al., 1984], and may promote the seaward transport of fine sediment in nepheloid layers [Gorsline, 1984]. It follows that the correlation observed between grain-size proxies and productivity indicators may be explained by a prevalence of nepheloid layers during intervals when the upwelling cell at Point Conception was in operation.

[28] This option satisfies a final, and critical observation. The $\%$ organic carbon record varies in approximate lockstep not only with inferred changes in grain size but also with sedimentary $\delta^{15} \mathrm{~N}$, relative abundance of upwelling-related planktonic foraminiferal species, opal content (Figure 4) and sea-surface temperature as indicated by the coiling ratio of $N$. pachyderma (Figure 2a). Furthermore, the organic carbon to $\mathrm{Al}$ ratio increases during the "upwelling" events inferred from the planktonic foraminiferal ${ }^{13} \mathrm{C}$ data (Figure 4d). Taken collectively, these data strongly imply that the organic carbon maxima seen downcore indicate episodes of upwelling-induced enhanced organic matter export from surface waters, followed by overprinting on the seafloor by contemporaneous physical sorting processes. An important implication of this scenario is that the surface ocean and seafloor off Point Conception have been tightly coupled both physically and biologically over much of the late Quaternary [Cannariato and Kennett, 1999].

\subsubsection{Floral and Faunal Relationships}

[29] A dynamic relationship exists between the distance from upwelling centers and both the type and quantity of biomass exported to the deep sea. This increases the complexity of paleoproductivity interpretations. At the beginning of an upwelling event, surface waters are colder, more nutrient rich, and have a lower phytoplankton biomass than the surrounding regions [Jones et al., 1983]. As surface waters warm with distance from the upwelling point, diatoms become dominant as a result of the high nutrient conditions, and out-competing other phytoplankton (such as coccolithophorids) where sufficient silica is available. At the point from the upwelling centre where the abundance of phytoplankton is the greatest, zooplankton (radiolaria and foraminifera) biomass begins to increase. Beyond this point phytoplankton biomass declines due to nutrient limitation, sinking and grazing [Jones et al., 1983]. The relative abundances of both phytoplankton and zooplankton can therefore provide important information about the structure of the upwelling cell over time.

[30] High relative abundances of G. bulloides occur throughout the 60-10 ka interval at ODP Hole 1017E. Most are associated with interstadial events, low $\delta^{13} \mathrm{C}$, high $\delta^{15} \mathrm{~N}$ and increases in percent carbonate and biogenic opal. Exceptions include IS 15 and 8, when low abundances of the species occur, and during the LGM, where high relative abundances occur independently of isotopic changes. During these exceptions, one or both phytoplankton proxies increase alongside G. bulloides relative abundance, implying that increases in abundance of this taxa relate to enhanced food supply. The association of G. bulloides with opal maxima in particular is consistent with variable upwelling intensity in the past. In addition, G. quinqueloba also increases in abundance most distinctly during IS events 9 , 10 and 11 and the Bølling. These data reinforce the inference that upwelling increased during these intervals.

[31] High abundances of upwelling associated foraminifera are commonly associated with decreases in $\delta^{13} \mathrm{C}$ 
recorded by planktonic foraminiferal carbonate, and may be related to upwelling through the following mechanism. Seawater in the photic zone is enriched in $\delta^{13} \mathrm{C}$ relative to atmospheric $\mathrm{CO}_{2}$ due to the higher affinity for ${ }^{12} \mathrm{CO}_{2}$ over ${ }^{13} \mathrm{CO}_{2}$ of the $\mathrm{CO}_{2}$-fixing enzyme of marine algae during photosynthesis. Subsequent bacterial decomposition of the ${ }^{12} \mathrm{C}$-enriched organic rain leads to decreased $\delta^{13} \mathrm{C}$ with depth in the water column and/or aging of a water mass [Hemleben and Bijma, 1993]. Thus upwelled water contains a signature of low $\delta^{13} \mathrm{C}$, which may be recorded in the tests of planktonic foraminifera secreted during the early stages of an upwelling event. Between 60 and 40 ka planktonic foraminiferal $\delta^{13} \mathrm{C}$ decreases simultaneously with increases in productivity proxies (organic carbon, opal, foraminiferal abundance) and indicators of upwelling $\left(\delta^{15} \mathrm{~N}\right)$. This correspondence supports the hypothesis of low $\delta^{13} \mathrm{C}$ being brought to the surface during upwelling episodes.

[32] This interpretation, however, is complicated by foraminiferal growth characteristics. Foraminifera do not secrete their tests in full carbon-isotopic equilibrium with seawater; metabolic processes may influence the $\delta^{13} \mathrm{C}$ of carbonate tests. Biological fractionation effects (vital effects) including symbiotic photosynthesis and foraminiferal respiration modify the $\delta^{13} \mathrm{C}$ content of $\mathrm{CO}_{2}$ in seawater between spines of spinose foraminifera [Berger and Vincent, 1986]. Symbiont photosynthesis enriches ${ }^{13} \mathrm{C}$ while foraminiferal respiration adds ${ }^{12} \mathrm{C}$ to the residual local $\Sigma \mathrm{CO}_{2}$ pool. For spinose species like $G$. bulloides, the interspine water may serve as a carbonate pool for calcification. The $\Sigma^{13} \mathrm{C}$ of the tests may thus depend in part on the relative balance between metabolism of the symbionts and respiration by the foraminifera itself. If this is the case the nonspinose species $N$. pachyderma, should be less susceptible to such species-dependent biological fractionation. This contrast could contribute to the more dramatic shifts in $\delta^{13} \mathrm{C}$ seen in the G. bulloides record (Figures 3d and 3e). As well, $N$. pachyderma also lives deeper in the water column where the $\delta^{13} \mathrm{C}$ of $\Sigma \mathrm{CO}_{2}$ can be expected to be more consistent through time.

[33] Considering that the observed sharp decreases in planktonic $\delta^{13} \mathrm{C}$ are most distinct in the G. bulloides record, and those prior to $25 \mathrm{ka}$ are coincident with increases in $\delta^{15} \mathrm{~N}$ and the flux of G. bulloides, it is concluded that the $\delta^{13} \mathrm{C}$ minima indicate upwelling episodes. This inference is fully consistent with that derived from the other proxies. Furthermore both possible explanations for the $\delta^{13} \mathrm{C}$ values recorded by $G$. bulloides require that the organism was either secreting carbonate only during the initial stages of an upwelling event (prior to the bulk of the ${ }^{12} \mathrm{C}$ being removed from the local $\Sigma \mathrm{CO}_{2}$ ) or that the organism grew very rapidly. Both these conclusions suggest that the dramatic increases in absolute abundance of $G$. bulloides relate to "blooms" of the species or short-duration intervals of extremely high population density in response to upwelling events.

\subsubsection{Preservation Versus Production}

[34] As oxidation of organic matter begins almost immediately after production and the ocean is understaturated with respect to silica, it remains possible that shifts in biogenic opal concentration and $\%$ organic carbon were not related to productivity changes, but rather preservation differences. Preservation of organic carbon at the site is discussed in section 5.1.1. We now address significant increases in biogenic opal at the Bølling and IS events 11 and 12, that suggest an active upwelling cell was operating at the site during those intervals. Ten to one hundred percent of silica produced in the euphotic zone dissolves in the upper 50-100 m of the water column [Nelson et al., 1995]. Silica dissolution is controlled by grazing (removal of organic matter from opal surfaces), seafloor transport (marine snow versus fecal pellets), and silicic acid concentration (interbasin fractionation, and upwelling; Ragueneau et al. [2000]). As mentioned earlier, increased transport of biogenic sediment to the seafloor via marine snow during warm intervals is supported by the record at ODP Hole 1017E. Preservation of biogenic opal in sediments depends upon sedimentation rate, bioturbation intensity and processes influencing the dissolution and solubility of opal [Ragueneau et al., 2000]. Any or all of these factors may have influenced the opal content down hole at Site 1017. Unfortunately, it is not possible to quantify their individual or collective impact.

[35] A further complication is presented by the analytical technique. At low sedimentary biogenic opal concentrations $(<10 \%)$, interference resulting from clay mineral presence can be significant. Part of the silicic acid released by dissolution of siliceous microfossils may reprecipitate with $\mathrm{Al}$ as amorphous Al-Si coatings on particles or as discrete authigenic clay minerals [Ragueneau et al., 2000]. Subsequent analysis of the opal content using the alkaline dissolution procedure of Mortlock and Froelich [1989] can extract extraneous Si from the amorphous coatings or mineral phases leading to an overestimation of the true biogenic opal concentration. This is in part a function of the sample digestion time, which in this study was kept to a reproducible minimum. However, because changes in opal concentration (Figure 4) do not correlate strongly with change in the fine grained sediment fraction (an indicated by major and minor element concentrations), it is suggested that the measured $\%$ opal reasonably represents the diatom content in the sediments. Furthermore as opal preservation increases with increased concentrations within the sediments, any change in opal production should be amplified in the record at ODP Hole 1017E.

[36] The correlation between \% opal and the other productivity indicators indeed suggests that productivity, and not analytical artifacts, provided the primary control on sedimentary opal content, with high productivity resulting in increased preservation of opal. However, if G. quinqueloba is associated with diatom blooms in modern sediment trap studies [Sautter and Sancetta, 1992; Sautter and Thunell, 1991], how well does opal production correlate with G. quinqueloba abundance (Figures 2 and 4)? The most dramatic increase in both $G$. quinqueloba relative abundance and opal\% coincides with the Bølling, with another increase in both proxies during IS 11. However, G. quinqueloba relative abundance increases during IS 9 and 10 are not reflected in the $\%$ opal record, perhaps due to the brevity $(<200$ years) of the climatic events that may not have been of insufficient duration to allow a significant 
increase in pore water dissolved silica concentration. Although a large increase in \% opal during IS 12 is not reflected in the G. quinqueloba relative abundance there is an increase in $G$. quinqueloba absolute abundance at this time.

\subsection{Processes Controlling Upwelling}

[37] The multiproxy data from ODP Hole 1017E demonstrate consistently that interstadials were more productive than stadials and imply that changes in upwelling intensity provided the primary control. Lags between higher SST and productivity occurred during some interstadials, however, suggesting that the interplay between biotic response and upwelling was complex. This may be the result of local effects in the Point Conception area such as the seasonal persistence and direction of local winds, or subaerial exposure of the shelf associated with drops in eustatic sea level and seaward migration of the upwelling center. Productivity at the site would also have been influenced by distal processes such as changes in the strength and depth of the California Undercurrent, as well as the strength of the California Current. These are assessed below.

\subsubsection{Wind Stress Curl and Upwelling}

[38] The modern annual cycle of wind stress in the region is controlled by the North Pacific High (a subtropical high over the eastern North Pacific) and a low pressure cell that lies over southwestern deserts of North America. In early spring the high pressure cell strengthens and moves northward, while the low deepens. At this time the predominant winds in the region change in direction from downwelling favorable (southerly) to upwelling favorable (northerly). During this interval, which lasts from April to October, winds are spatially inhomogeneous, with maximum winds occurring off Point Conception, and the Southern California Bight being relatively sheltered [Winant and Dorman, 1997]. The acceleration of airflow at Point Conception results from the $90^{\circ}$ change in orientation of the highrelief coastline associated with the Santa Ynez Mountains [Münchow, 2000]. Thus during intervals of persistent northerly winds an upwelling cell forms off Point Conception. During winter, the North Pacific High weakens and moves southward, allowing cyclones and anticyclones to pass over the region. These storm systems result in spatially uniform wind fields and weak monthly average winds.

[39] It has been suggested that the North Pacific High weakened and moved south during the last glacial as a high pressure system established over the Laurentide Ice Sheet [COHMAP members, 1988]. Cooler continental temperatures relative to the ocean during this time may have resulted in weaker northerly winds and/or a change in predominant wind direction. Consequently the upwelling cell at Point Conception may not have existed during cool intervals of the last glacial and productivity would have been reduced as a result of changes in atmospheric circulation. That productivity increases during interstadial events suggests that during these times, persistent northerly winds occurred off Point Conception as if the North Pacific High had strengthened and moved northward despite the presence of the Laurentide Ice Sheet. These observations support previous work suggesting an atmospheric teleconnection with Greenland [Hendy and Kennett, 1999].

\subsubsection{Nutrient Conveyor}

[40] In addition to the presence of upwelling favorable winds, the high nutrient content of water welled up at Point Conception may have played a role in productivity at the site. At present, water supplied to the surface during upwelling is derived from $\sim 300 \mathrm{~m}$ depth, which approximately corresponds to the core of the poleward undercurrent beneath the California Current. The undercurrent transports water northward from the Eastern Tropical North Pacific (ETNP) denitrification zone at depths from $\sim 100$ to $500 \mathrm{~m}$. Upwelling of this water at Site 1017, brings nutrients and high $\delta^{15} \mathrm{~N}$ to the surface. The cause of undercurrent flow is not fully understood but may be related to cyclonic wind stress curl or alongshore pressure gradients. Regardless, it is clear that the undercurrent is trapped on the coast. The strength of the undercurrent is not necessarily related to upwelling and is generally not correlated with local wind intensity [Smith, 1992].

[41] The isotopic composition of particulate nitrogen can be used as a proxy for both upwelling along the western North American margin as well as a fingerprint for the source of the upwelled water. The rationale for this claim is based on several observations. First, in nitrate limited surface waters, such as in the California Current, complete nitrate utilization occurs. The $\delta^{15} \mathrm{~N}$ of phytoplankton in such waters directly reflects the $\delta^{15} \mathrm{~N}$ of the upwelled nitrate, as no net isotopic fractionation can occur when all nitrate is consumed. Bacterial denitrification in the ETNP oxygen minimum zone, a source area for California Undercurrent water, strongly discriminates against ${ }^{15} \mathrm{~N}$, yielding isotopically light products $\left(\mathrm{N}_{2} \mathrm{O}, \mathrm{N}_{2}\right)$ and isotopically heavy residual nitrate $(+7.5$ to $+18.5 \%$; Brandes et al. [1998]). Northward transport, upwelling, and biologic uptake of the "heavy" residual nitrate accounts for the high $\delta^{15} \mathrm{~N}$ values of particulate nitrogen in modern surface waters along the Californian Margin [Altabet et al., 1999] and in the underlying sediments [Emmer and Thunell, 2000; Ganeshram and Pedersen, 1998; Kienast et al., 2002; Liu and Kaplan, 1989].

[42] We suggest therefore that intervals where high $\delta^{15} \mathrm{~N}$ values are recorded during the last $60 \mathrm{ka}$ were related to the upwelling of subsurface waters that originated in the ETNP and were transported along the North America Margin by the California Undercurrent. In this view, $\delta^{15} \mathrm{~N}$ may be considered a proxy for the existence of a nutrient conveyor running from south to north The correlation between high $\delta^{15} \mathrm{~N}$ values and other indicators of productivity (total organic carbon, carbonate, G. bulloides abundance etc.) during interstadials suggest that the postulated nutrient conveyor has been an important factor controlling productivity off southern California.

[43] $\delta^{15} \mathrm{~N}$ cannot be used as a proxy in reverse, however, as intervals of low $\delta^{15} \mathrm{~N}$ may or may not be related to decreases in upwelling. Three scenarios (Figure 6) illustrate why $\delta^{15} \mathrm{~N}$ in export production was likely low at Site 1017 during cool intervals whether or not upwelling was occurring. First, the simple absence of upwelling in the region (Figure 6b) may have resulted in incorporation of isotopi- 


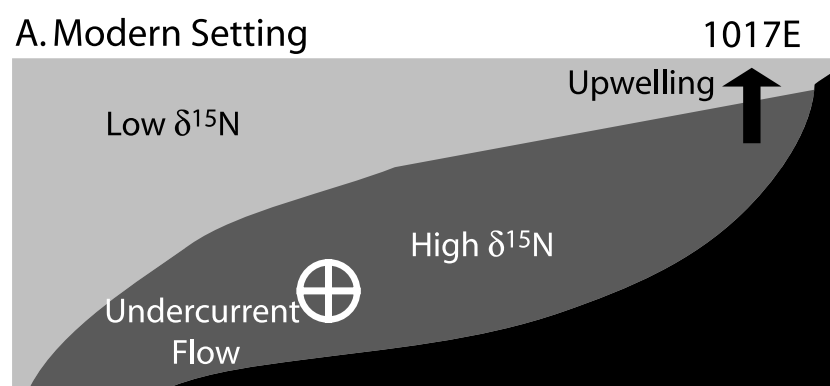

B. No upwelling

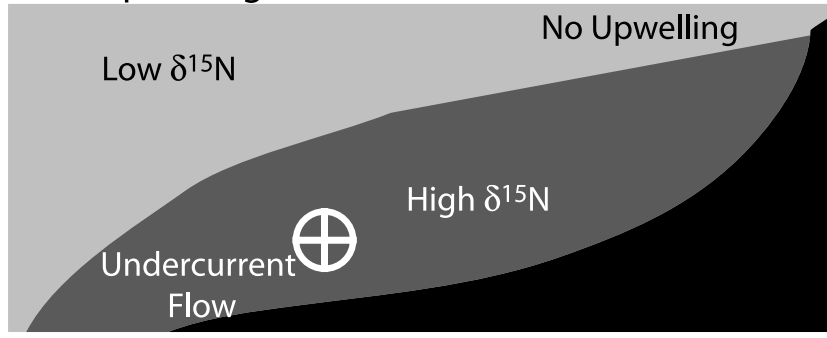

C. Gyral spinup

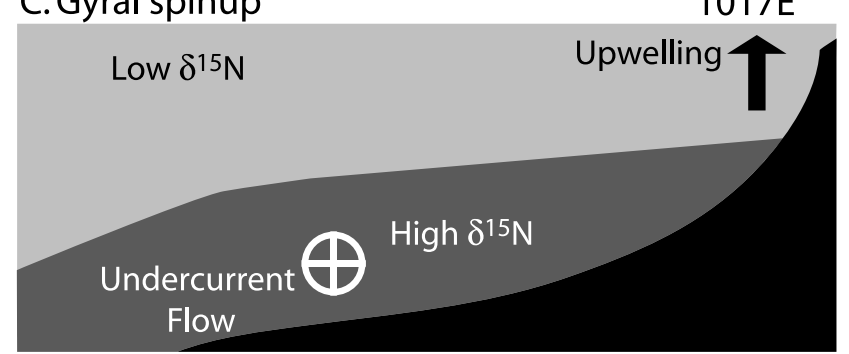

D. No Undercurrent

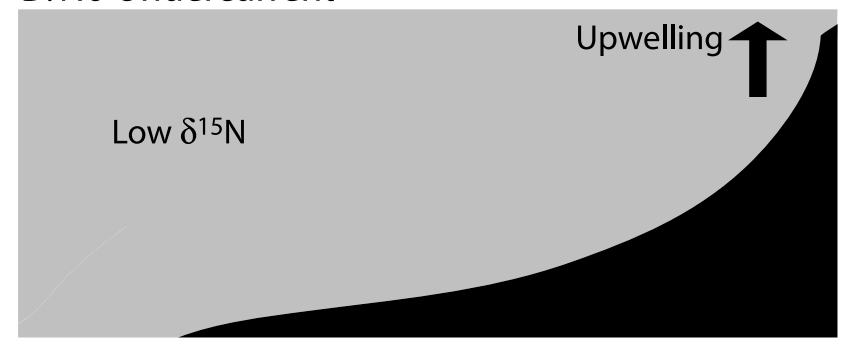

Figure 6. Cross section showing scenarios resulting in the delivery of high or low $\delta^{15} \mathrm{~N}$ water mass values to ODP Hole 1017E. (a) The modern setting showing the transport of high $\delta^{15} \mathrm{~N}$ values up the coast in the California Undercurrent and upwelling at the site. (b) The no-upwelling case despite their being an undercurrent flow similar to that of the modern setting. (c) A stronger North Pacific Gyre circulation results in a deeper undercurrent flow. (d) The case with diminished undercurrent flow and/or no denitrification in the eastern tropical North Pacific (ETNP).

cally depleted $\delta^{15} \mathrm{~N}$ in organic matter, regardless of undercurrent flow conditions. The second, increased spin on the North Pacific Gyre would have resulted in a deeper subsurface flow along the California Margin (Figure 6c). This would have pushed undercurrent water below the depth of water uplifted by upwelling. Third, diminished subsurface flow from, and/or decreased denitrification in the ETNP, in spite of continued upwelling in the region (Figure 6d) would have resulted in upward advection of isotopically light nitrate. On the basis of these scenarios, it can be assumed that upwelling occurred when sedimentary $\delta^{15} \mathrm{~N}$ values were high, but it cannot be assumed that upwelling ceased during intervals of low $\delta^{15} \mathrm{~N}$. Further, the absence of high productivity during intervals of low $\delta^{15} \mathrm{~N}$ suggests that if upwelling was still occurring, the nutrient content of the welled up water was indistinguishable from surface waters at the time.

[44] The California Undercurrent is possibly driven by changes in alongshore pressure gradients or sea level height on the North American Margin, such as may occur with changes in tradewind strength and/or upwelling. If a steeper thermoclinal gradient across the Pacific [Andreasen and Ravelo, 1997] and intensified trade winds occurred during cool intervals of the last glacial, relatively low sea levels may have resulted in the ETNP. Diminished coastal upwelling on the California Coast during stadial events as demonstrated at ODP Hole 1017E would have resulted in higher coastal sea level. A proposed weaker California Current [Doose et al., 1997; Herbert et al., 2001] would have reduced transport of surface water into the ETNP and contributed to a longshore sea level pressure gradient unfavorable to undercurrent flow. Thus a weaker California
Undercurrent has been suggested during the last glacial [Kienast et al., 2002], and during stadials [Hendy and Kennett, 2003]. A possible reduction in the flow of the California Undercurrent would have diminished the subsurface nutrient concentrations on the California Margin, resulting in a less pronounced biological response to upwelling. Indeed modeling of intermediate waters during the well-known 1976-1977 climate regime shift produced a similar nutrient change off the coast of California and Baja California [Auad et al., 2003]. Thus it is feasible that changes in the nutrient content of intermediate waters off Point Conception also played a role in the history of productivity at ODP Hole 1017E.

\subsubsection{Different Climate Conditions, Different Productivity Responses}

[45] Finally the response of biological productivity at Point Conception during the last $60 \mathrm{Ka}$ can be divided into three distinct intervals. First during MIS 3, a flickering switch appeared to turn the upwelling cell at Point Conception on during warm interstadial and off during cool stadial events. Second, during MIS 2 or the LGM, productivity, not necessarily associated with intensified upwelling increased. Finally high productivity occurred throughout the Holocene with some decrease from early to late Holocene.

[46] As mentioned in prior discussion, the productivity changes observed during MIS 3 can be explained by the presence of an upwelling cell during interstadials and the possibility of a nutrient-rich water mass in the subsurface. Cool stadial events were the least productive intervals of the last glacial with no apparent upwelling and/or California Undercurrent flow. What then occurred during the LGM? Productivity (high \% carbonate and opal) appears to increase 
during LGM, unlike other cool intervals during the last $60 \mathrm{Ka}$. The increase begins around $25 \mathrm{Ka}$ with a short duration decrease during IS event 2 (a distinct reversal of the productivity pattern demonstrated during MIS 3 interstadial events). One possible explanation is that high organic carbon concentrations are related to $1-3 \mathrm{~cm}$ thick sand layers associated with the MIS 2. Sand layers may prevent the diffusion of oxygen into the sediments increasing the preservation and consequently concentration of organic carbon as well as quickly burying the organic rich sediment. However, the productivity decrease observed during IS event 2 cannot be explained by the absence of sand layers and thus we contend that organic carbon and opal concentrations are indeed related to productivity at the site.

[47] High productivity without changes in surface water chemistry $\left(\delta^{13} \mathrm{C}\right.$ and $\delta^{15} \mathrm{~N}$ implying upwelling) may be explained by either by the increased relative advection of nutrient-rich California Current water into the region compared to other competing water masses [Hendy, 2000] or by a general increase in nutrient content of the California Current via the entire North Pacific nutrient budget. This second hypothesis, however, is not supported by the productivity history of the North Pacific [Kienast et al., 2004] The increase in productivity at the site after $25 \mathrm{Ka}$ is also in direct conflict with evidence from alkenone temperature estimates from more southerly sites [Herbert et al., 2001] that suggest an increase in the advection of gyral water into the region at that time. Another possibility remains that rather than taking place over a brief but intense seasonal interval, upwelling during the LGM occurred throughout the year although to a lesser extent than present. This may be the case if storm frequency intensified, increasing the mixed layer depth in the region. Although the behavior of productivity at ODP Hole 1017E is not fully understood for the LGM, it is apparent that the productivity response during this interval cannot be used as an analogy for stadial events.

\section{Conclusions}

[48] The upwelling cell at Point Conception existed intermittently during MIS 3 of the last glacial, generally switching on during warm intervals and off during cool. High organic carbon, opal, carbonate and G. bulloides and G. quinqueloba abundance indicate increased productivity during intervals of increased dextral $N$. pachyderma and decreased planktonic $\delta^{18} \mathrm{O}$. The coupling between high productivity and increased SST was not always synchronous, however, suggesting that processes that increased SSTs in the Southern California Bight differ from those that drove productivity. The magnitude of upwelling events during warm intervals was apparently related to the magnitude and duration of interstadial events, such that upwelling during the Bølling was greater than any other time during the last $60 \mathrm{ka}$.

[49] Changes in the intensity, direction and/or persistence of local winds play a major role in occurrence of upwelling at the Point Conception site today and almost certainly did equally in the past. As the California coast warmed at the initiation of interstadials, the continent/ocean temperature difference would have increased, strengthening winds, while the North Pacific High Pressure system would have migrated north, changing the persistent wind direction. Simultaneously the California Undercurrent apparently resumed or strengthened its flow, increasing the delivery of high-nutrient subsurface water to the region. The multiproxy approach used here shows clearly that high-frequency climate change sensitively modulated export production on the California Margin.

[50] The full geographical expression of such variability remains to be mapped but recent data from sites to the north [Kienast et al., 2002; Kienast and McKay, 2001; McKay et al., 2004] and south [Ortiz et al., 2004] imply that the entire margin between at least Mexico and Canada responded to the Dansgaard-Oeschger climate flickers on the submillennial temporal scale. Decreased productivity at ODP Hole 1017E during stadials in contrast to increased productivity along the North American Margin during interstadials may have contributed to decreases in the oxygen concentration of intermediate waters, and consequently denitrification and ultimately atmospheric $p \mathrm{CO}_{2}$. However, as the nutrient content of subsurface waters may have played a role in the productivity history of the California Margin and this water mass is associated with low oxygen intermediate water, further development of bottom water oxygen indicators at the site is required before a definitive conclusion can be drawn. Observed submillennial climate variability during the last glacial clearly extended from the atmosphere to well below the surface of the ocean. Explaining this simple observation remains a challenge to climate physicists.

[51] Acknowledgments. TFP is grateful to the Natural Sciences and Engineering Research Council of Canada and the Faculty of Graduate Studies at the University of British Columbia for partial funding of this research. JK thanks the National Science Foundation (NSF grant OCE0242041 (Marine Geology and Geophysics) for financial support. Funding for radiocarbon analyses was provided by the Institute of Geophysics and Planetary Physics, Lawrence Livermore National Laboratory, University of California (LLNL), and the Center for Accelerator Mass Spectrometry, LLNL. This research used samples provided by the Ocean Drilling Program (ODP). ODP is sponsored by the United States National Science Foundation (NSF) and participating countries under the management of the Joint Oceanographic Institutes (JOIs) INC.

\section{References}

Alldredge, A. L., U. Passow, and B. E. Logan (1993), The abundance and significance of a class of large, transparent organic particles in the ocean, Deep Sea Res. Part I, 40, 1131 - 1140.

Altabet, M. A., C. Pilskaln, R. Thunell, C. Pride, D. Sigman, F. Chavez, and R. Francois (1999), The nitrogen isotope biogeochemistry of sinking particles from the margin of the eastern North Pacific, Deep Sea Res. Part I, 46, 655679.

Andreasen, D. J., and A. C. Ravelo (1997) Tropical Pacific Ocean thermocline depth reconstruction for the Last Glacial Maximum, Paleoceanography, 12, 395-413.
Auad, G., J. P. Kennett, and A. J. Miller (2003), North Pacific Intermediate Water response to a modern climate warming shift, J. Geophys. Res., 108(C11), 3349, doi:10.1029/ 2003JC001987.

Behl, R. J. (1995), Sedimentary facies and sedimentology of the Late Quaternary Santa Bar- 
bara Basin (Site 893), Proc. Ocean Drill. Program Sci. Results, 146, 295-308.

Behl, R. J., and J. P. Kennett (1996), Evidence for brief interstadial events in the Santa Barbara Basin, NE Pacific during the past 60 Kyr, Nature, 379, $243-246$.

Berger, W. H., and E. Vincent (1986), Deep-sea carbonates: Reading the carbon-isotope signal, Geol. Rundsch., 75, 249-269.

Brandes, J. A., A. H. Devol, T. Yoshinari, D. A. Jayakumar, and S. W. A. Naqvi (1998), Isotopic composition of nitrate in the central Arabian Sea and western tropical North Pacific: A tracer for mixing and nitrogen cycles, Limnol. Oceanogr. $43,1680-1689$.

Calvert, S. E., B. L. Cousens, and M. Y. S. Soon (1985), An X-ray fluorescence spectrometric method for the determination of major and minor elements in ferromanganese nodules, Chem. Geol., 51, 9-18.

Cannariato, K. G., and J. P. Kennett (1999), Climatically related millennial-scale fluctuation in the strength of the California margin oxygen-minimum zone during the past 60 k.y., Geology, 27, 975-978.

Cannariato, K. G., J. P. Kennett, and R. J. Behl (1999), Biotic response to late Quaternary climate flickers in the Santa Barbara Basin: Ecological and evolutionary implications, Geology, 27, 63-66.

COHMAP members (1988), Climatic changes of the 18,000 years: Observations and model simulations, Science, 241, 1043-1052.

Coplen, T. B. (1997), Editorial: More uncertainty than necessary, Paleoceanography, 11, 369370

Doose, H., F. G. Prahl, and M. W. Lyle (1997), Biomarker temperature estimates for modern and last glacial surface waters of the California Current system between $33^{\circ}$ and $42^{\circ} \mathrm{N}$, Paleoceanography, 12, 615-622.

Emmer, E., and R. C. Thunell (2000), Nitrogen isotope variations in Santa Barbara Basin sediments: Implications for denitrification in the eastern tropical North Pacific during the last 50,000 years, Paleoceanography, 15, $377-$ 387.

Flückiger, J., T. Blunier, B. Stauffer, J. Chappellaz, R. Spahni, K. Kawamura, J. Schwander, T. F. Stocker, and D. Dahl-Jensen (2004), $\mathrm{N}_{2} \mathrm{O}$ and $\mathrm{CH}_{4}$ variations during the last glacial epoch: Insight into global processes, Global Biogeochem. Cycles, 18, GB1020, doi:10.1029/ 2003GB002122.

Ganeshram, R. S., and T. F. Pedersen (1998), Glacial-interglacial variability in upwelling and bioproductivity off NW Mexico: Implications for Quaternary palaeoclimate, Paleoceanography, 13, 634-645.

Ganeshram, R. S., T. F. Pedersen, S. E. Calvert, and J. W. Murray (1995), Large changes in oceanic nutrient inventories from glacial to interglacial periods, Nature, 376, 755-758.

Ganeshram, R. S., T. F. Pedersen, S. E. Calvert, G. W. McNeill, and M. R. Fontugne (2000), Glacial-interglacial variability in denitrification in the World's Oceans: Causes and consequences, Paleoceanography, 15, 361-376.

Gorsline, D. S. (1984), A review of fine-grained sediment origins, characteristics, transport and deposition, in Fine Grained Sediments: Deep Water Processes and Facies, edited by D. A. V. Stow and D. J. W. Piper, pp. 17-33, Blackwell Sci., Malden, Mass.

Hedges, J. I., and R. G. Keil (1995), Sedimentary organic matter preservation: An assessment and speculative synthesis, Mar. Chem., 49, $81-115$
Heider, F., J. Bock, I. Hendy, J. Kennett, J. Matzka, and J. Schneider (2001), A latest Quaternary rock magnetic record of climatic and oceanic change: Tanner Basin, California Borderland, Geol. Soc. Am. Bull., 113, 346-359.

Hemleben, C., and J. Bijma (1993), Foraminiferal population dynamics and stable carbon isotopes, in Carbon Cycling in the Glacial Ocean: Constraints on the Ocean's Role in Global Change, Quantitative Approaches in Paleoceanography, edited by R. Zahn et al., pp. 145-166, Springer-Verlag, New York.

Hendy, I. L. (2000), Rapid climate change recorded in the North Pacific: Triggers, processes and effects, Univ. of Calif., Santa Barbara.

Hendy, I. L., and J. P. Kennett (1999), Latest Quaternary North Pacific surface-water responses imply atmosphere-driven climate instability, Geology, 27, 291-294.

Hendy, I. L., and J. P. Kennett (2000), Dansgaard/ Oeschger Cycles and the California Current System: Planktonic foraminiferal response to rapid climate change in Santa Barbara Basin, ODP Hole 893A, Paleoceanography, $15,30-42$.

Hendy, I. L., and J. P. Kennett (2003), Tropical forcing of North Pacific Intermediate Water during late Quaternary climate change, Quat. Sci. Rev., 22, 673-689.

Hendy, I. L., J. P. Kennett, E. B. Roark, and B. L. Ingram (2002), Apparent synchroneity of submillennial scale climate events between Greenland and Santa Barbara Basin, California from 30-10 ka., Quat. Sci. Rev., 21, 1167-1184.

Herbert, T. D., J. D. Schuffert, D. Andreasen, L. Heusser, M. Lyle, A. Mix, A. C. Ravello, L. D. Stott, and J. C. Herguera (2001), Collapse of the California Current during glacial maxima linked to climate change on land, Science, 293, 71-76.

Imbrie, J., and N. G. Kipp (1971), A new micropaleontology method for quantitative paleoclimatology: Application to a late Pleistocene Caribbean core, in Late Cenozoic Glacial Ages, edited by K. K. Turekian, pp. 71-181, Yale Univ. Press, New Haven, Conn.

Irino, T., and T. Pedersen (2000), Geochemical character of glacial to interglacial sediments at Site 1017, Southern Californian Margin: Minor and trace elements, Proc. Ocean Drill. Program Sci. Results, 167, 263-271.

Ivanochko, T. S., and T. F. Pedersen (2004), Determining the influences of Late Quaternary ventilation and productivity variations on Santa Barbara Basin sedimentary oxygenation: A multi-proxy approach, Quat. Sci. Rev., 23 467-480.

Jones, B. H., K. H. Brink, R. Dugdale, D. W. Stuart, J. Van-Leer, D. Blasco, and J. C. Kelley (1983), Observations of a persistent upwelling center off Point Conception, California, in Coastal Upwelling, Its Sediment Records: Part $A$, Responses of the Sedimentary Regime to Present Coastal Upwelling, edited by E. Suess and J. Thiede, pp. 37-60, Plenum, New York.

Kennett, J. (1995), Latest Quaternary benthic oxygen and carbon isotope stratigraphy: Hole 893A, Santa Barbara Basin, California, Proc Ocean Drilling Program Sci. Results, 146, 3 18.

Kennett, J., E. Roark, K. Cannariato, B. Ingram, and R. Tada (2000), Latest Quaternary paleoclimatic and radiocarbon chronology, Hole $1017 \mathrm{E}$, Southern California margin, Ocean Drill. Program Initial Rep., 167, 249-254.

Kienast, S. S., and J. L. McKay (2001), Sea surface temperatures in the subarctic northeast
Pacific reflect millennial-scale climate oscillations during the last 16 kyrs, Geophys. Res. Lett., 28, 1563-1566.

Kienast, S. S., S. E. Calvert, and T. F. Pedersen (2002), Nitrogen isotope and productivity variations along the northeast Pacific margin over the last 120 kyr: Surface and subsurface paleoceanography, Paleoceanography, 17(4), 1055 , doi:10.1029/2001PA000650

Kienast, S. S., I. L. Hendy, J. Crusius, T. F. Pedersen, and S. E. Calvert (2004), Export production in the subarctic North Pacific over the last 800 kyrs: No evidence for iron fertilization?, J. Oceanogr, 60, 189-203.

Kincaid, E., R. C. Thunell, J. Le, C. B. Lange, A. L. Weinheimer, and F. M. H. Reid (2000), Planktonic foraminiferal fluxes in the Santa Barbara Basin: Response to seasonal and interannual hydrographic changes, Deep Sea Res. Part II, 47, 1157-1179.

Koblinsky, C. J., J. J. Simpson, and T. D. Dickey (1984), An offshore eddy in the California Current System. Part II: Surface manifestations, Progr. Oceanogr., 13, 51-69.

Liu, K. K., and I. R. Kaplan (1989), The eastern tropical Pacific as a source of N-15-enriched nitrate in seawater off southern California, Limnol. Oceanogr., 34, 820-830.

Lynn, R. J., and J. J. Simpson (1987), The California Current System: The seasonal variability of its physical characteristics, J. Geophys. Res., 92, 12,947-12,966.

McKay, J. L., T. F. Pedersen, and S. S. Kienast (2004), Organic carbon accumulation over the last 16 kyr off Vancouver Island, Canada: Evidence for increased marine productivity during the deglacial, Quat. Sci. Rev., 23 , 261-281.

Mortlock, R. A., and P. N. Froelich (1989), A simple method for a rapid determination of biogenic opal in pelagic marine sediments, Deep Sea Res., 36, 1415-1426.

Münchow, A. (2000), Wind stress curl forcing of the coastal ocean near Point Conception, California, J. Phys. Oceanogr., 30, 1265-1280.

Nelson, D. M., P. Treguer, M. A. Brzezinski, A. Leynaert, and B. Queguiner (1995), Production and dissolution of biogenic silica in the ocean: Revised global estimates, comparison with regional data and relationship to biogenic sedimentation, Global Biogeochem. Cycles, 9, 359-372.

Ortiz, J. D., and A. C. Mix (1992), The spatial distribution and seasonal succession of planktonic foraminifera in the California Current off Oregon, September 1987-September 1988, in Upwelling Systems: Evolution Since the Early Miocene, edited by C. P. Summerhayes, W. L. Prell, and K. C. Emeis, pp. 197-213, Geol. Soc., London.

Ortiz, J. D., S. O'Connell, J. DelViscio, W. Dean, J. Carriquiry, T. Marchitto, Y. Zheng, and A. van Geen (2004), Enhanced marine productivity off western North America during warm climate intervals of the past $52 \mathrm{kyr}$, Geology, 32(6), 521-524.

Pak, D., and J. P. Kennett (1997), Planktonic foraminiferal proxies of hydrographic conditions in the Santa Barbara Basin, Eos Trans. $A G U, 78(46)$, Fall Meet. Suppl., F359.

Pak, D., and J. P. Kennett (2002), A foraminiferal isotopic proxy for upper water mass stratification, J. Foraminiferal Res., 32, 319-327.

Ragueneau, O., et al. (2000), A review of the $\mathrm{Si}$ cycle in the modern ocean: Recent progress and missing gaps in the application of biogenic opal as a paleoproductivity proxy., Global Planet. Change, 26, 317-365. 
Ransom, B., K. F. Shea, P. J. Burkett, R. H. Bennett, and R. Baerwald (1998), Comparison of pelagic and nepheloid layer marine snow: Implications for carbon cycling, Mar. Geol., 150, 39-50.

Reynolds, L., and R. C. Thunell (1986), Seasonal production and morphologic variation of $\mathrm{NeO}$ globoquadrina pachyderma (Ehrenberg) in the northeast Pacific., Micropaleonology, 32, $1-18$.

Sautter, L. R., and C. Sancetta (1992), Seasonal associations of phytoplankton and planktic foraminifera in an upwelling region and their contribution to the sea-floor, Mar. Micropaleontol., 18, 263-278.

Sautter, L. R., and R. C. Thunell (1991), Planktonic foraminiferal response to upwelling and seasonal hydrographic conditions: Sediment trap results from San Pedro Basin, Southern Califronia Bight, J. Foraminiferal Res., 21, 347-363.

Seki, O., R. Ishiwatari, and K. Matsumoto (2002), Millennial climate oscillations in NE Pacific surface waters over the last 82 kyr: New evidence from alkenones, Geophys. Res. Lett., 29(23), 2144, doi:10.1029/ 2002GL015200

Seuss, E. (1973), Interaction of organic compounds with calcium carbonate-II. Organo- carbonate association in Recent sediments, Geochim. Cosmochim. Acta, 37, 2435-2447.

Sigman, D. M., M. A. Altabet, R. Michener, D. C. McCorkle, B. Fry, and R. M. Holmes (1997), Natural abundance-level measurement of the nitrogen isotopic composition of oceanic nitrate: An adaptation of the ammonia diffusion method, Mar. Chem., 57, 227-242.

Smith, R. L. (1992), Coastal upwelling in the modern setting, in Upwelling Systems: Evolution Since the Early Miocene, edited by C. P. Summerhayes, W. L. Prell, and K. C. Emeis, pp. 9-28, Geol. Soc., London.

Strickland, J. D. H., and T. R. Parsons (1972), Apractical Handbook of Seawater Analysis, 311 pp., Fish. Res. Board of Can., Halifax, Nova Scotia.

Stuiver, M., J. Reimer, E. Bard, J. Beck, G. S. Burr, K. A. Hughen, B. Kromer, G. McCormac, J. VanDerPlight, and M. Spurk (1998), INTCAL98 radiocarbon age calibration, 24,000 cal BP, Radiocarbon, 40, $1041-$ 1083.

Tada, R., S. Sato, T. Irino, H. Matsui, and J. P. Kennett (2000), Millennial-scale compositional variations in Late Quaternary sediments at Site 1017, Southern California, Proc. Ocean Drill. Program Sci. Results, 167 277-296.
Tanaka, N., and R. Tada (2000), Calcareous nannofossil assemblages of the last 27 k.y. in hole 1017E, Santa Lucia Slope, off Point Conception, Proc. Ocean Drill. Program Sci. Results, 167, 303-308.

Tyson, R. V. (1987), The genesis and palynofacies characteristics of marine petroleum source rocks, in Marine Petroleum Source Rocks, edited by J. Brooks and A. J. Fleet, pp. $47-$ 67, Geol. Soc., London.

Winant, C. D., and C. E. Dorman (1997), Seasonal patterns of surface wind stress and heat flux over the Southern California Bight, J. Geophys. Res., 102, 5641-5653.

I. L. Hendy, Department of Geological Sciences, University of Michigan, Ann Arbor, MI 48109, USA. (ihendy@umich.edu)

J. P. Kennett, Department of Geological Sciences and Marine Science Institute, University of California, Santa Barbara, CA 931069630, USA.

T. F. Pedersen, School of Earth and Ocean Sciences, University of Victoria, P.O. Box 3055 , STN CSC, Victoria, BC V8W 3P6, Canada.

R. Tada, Geological Institute, University of Tokyo, 7-3-1 Hongo, Tokyo 113-0033, Japan. 